\title{
WHO ARE THEY?
}

\section{MRS. JOHN HUBBARD}

Grenfell, Sask.

The birds that we see in winter are a motley crew. Some of them are birds that are with us all year round like the English Sparrow, the Magpie, the Sharp-tailed and Ruffed Grouse, the Hairy and Downy Woodpeckers.

Others are summer visitors, birds that for some reason or other don't get away with their fellows to the South. Immaturity or injuries may account for some of these stragglers.

A third group are birds that live further north and pay us visits during the winter.

One of the most common of the northern visitors is the little Redpoll. This small member of the large sparrow clan (it is about 5 inches in length) has the usual brownish sparrow striping but has a bright red cap. A rosy colouring on breast and rump appears on male birds and to lc. .r extent on others.

Two slightly larger members of the sparrow family that visit orchard and windbreaks in winter are the Evening and Pine Grosbeaks.

The Pine Grosbeak is smaller than a Robin and is mainly grey in colour with the heavy beak that gives it its name. Some birds, however, are so heavily tinted with rosy hues on head, back, rump and breast that they are breathtakingly beautiful in their sombre winter setting. Others are tinted more or less heavily with varying shades of yellow or rust.

The Evening Grosbeak is smaller and not so common (I believe). In full colour it is a striking bird in brilliant black, white and yellow. The more common colouring is a dull or dirty yellow with black and white wings.

All these winter members of the sparrow clan have cheerful songs or calls.

Another handsome winter visitor is the Bohemian Waxwing, a larger and greyer edition of the summer Cedar Waxwing. Seen at a distance the Waxwing can be recognized by its crest and yellow tip on tail. But it is worth a closer look. Many colours are blended together to make its soft silky plumage a thing of beauty. The bits of bright red on wing feathers that give it is name (waxwing) add to the whole effect.

Another striking winter bird is the Snowy Owl, an infrequent visitor from the far north. Seen in his spotless white plumage this great bird with a wingspread of up to five feet is something to be remembered for all your life. However, many of these round-headed hornless owls are quite heavily barred with dark. This owl is as large or larger than the Great Horned Owl but does not have the noticeable "horns". Also its markings (when not in the allwhite plumage) are much heavier than that of the Great Horned Owl.

The Snow Bunting, another sparrow, is a frequent winter visitor. White is the predominant colour on this bird, with black and rusty as second colours. They are more often seen in large flocks than as individuals.

\section{A SUGGESTION}

\section{AUGUST J. BREITUNG}

If there are sufficient Blue Jay subscribers in Manitoba and Alberta, then I agree with Dr. George Leddingham's suggestion on inside back cover of July, August, September number to change the society's name from "Saskatchewan Natural History Society" to "Prairie Natural History Society." Also, the title of the magazine could be changed from "The Blue Jay" to "The Prairie Naturalist" which would be more appropriate. In addition, the cover illustration could be deleted. For example, the Canadian Field Naturalist was formerly known as "The Ottawa Naturalist."

The present title, "The Blue Jay" is liable to be misinterpreted as an ornithologists magazine, by those not familiar with it.

Note: A thorough discussion is invited.-Ed. 